\title{
Konsep Dasar Hukum Sebagai Norma Sosial: Studi Pada UU No 1 Tahun 1974 Dan Kompilasi Hukum Islam
}

\author{
Suprihatin
}

Fakultas Agama Islam, Universitas Islam “45” Bekasi

Korespondensi: shatin421@gmail.com

Info Artikel

Naskah diterima : 2 Mar 2020| Revisi : 26 Mar 2020| Disetujui : 2 Apr 2020

\begin{abstract}
Abstrak
Tujuan dari penulisan makalah ini adalah untuk mengetahui konsep dasar hukum sebagai norma sosial (studi pada UU No 1 tahun 1974 dan KHI). Focus kajian pada aspek nilai-nilai dasar hukum dan pada aspek penegakan hukum keluarga. Adapun yang menjadi alasan mengapa dua aspek tersebut perlu dikaji karena adanya fenomena unik dalam penerapan hukum keluarga yang belum bisa diterima seratus persen oleh masyarakat Indonesia tetapi eksistensinya masih dipertahankan oleh pemerintah. Metode yang digunakan dalam penulisan makalah ini adalah metode perpustakaan (library research). Makalah ini menghasilkan dua hal. Pertama, bahwa nilai-nilai dasar yang ada pada hukum keluarga di Indonesia adalah keadilan dan kemanfaatan. Kedua nilai tersebut saling menunjang. Namun kedua nilai dasar hukum tersebut belum menghasilkan ketertiban seratus persen dalam masyarakat. Hal ini dikarenakan pilihan pemerintah dalam menggunakan metode perumusan hukum dengan metode analisis normative sehingga tidak bersifat otoriter dan tidak memiliki sasaran untuk mengharuskan masyarakat untuk tunduk pada hukum keluarga secara paksa. Namun kekurangan metode ini dapat ditutupi dengan konten hukum yang berkemampuan untuk merubah masyarakat untuk mentransformasi diri tunduk pada hukum keluarga ketika sudah mendapatkan pemahaman yang tepat dan apabila mendapatkan permasalahan hukum. Kedua, Penegakan hukum keluarga Islam telah ditunjang oleh pranata hukum dan pranata sosial. Sebagian masyarakat telah mengunakan pranata tersebut dalam mendapatkan keadilan dan kemanfaatan, sehingga hukum keluarga dapat berfungsi sebagai institusi sosial yang melindungi masyarakat.
\end{abstract}

Kata kunci: Hukum, Norma Sosial, Keadilan, Kemanfaatan, Institusi Sosial

\begin{abstract}
The purpose of this paper is to find the basic concepts of law as social norms on basic value of family law and on family law enforcement. As for the reasons why these two aspects need to be examined because there is a unique phenomenon in the application of family law that cannot be accepted one hundred percent by the people of Indonesia
\end{abstract}


but its existence is still maintained by the government. The method used the library method (library research). There are two results in this paper. First, that the basic values that exist in family law in Indonesia are justice and expediency. These two values support each other. However, the two basic values of the law have not resulted in one hundred percent order in society. This is because the government's choice in using the method of formulating the law with the normative analysis method so that it is not authoritarian and does not have the goal of inviting the public to comply with family law. However, the lack of this method can be covered with legal content that is capable of changing society to transform themselves subject to family law when it has gotten the right understanding and when getting legal problems. Secondly, the enforcement of Islamic family law has been supported by legal and social institutions. Some communities have used these institutions in obtaining justice and benefits, so that family law can function as a social institution that protects the community.

Keywords: Law, Social Norm, Justice, expediency, social institution

\section{PENDAHULUAN}

\section{Latar Belakang Masalah}

Pada dasarnya, manusia merupakan makhluk sosial sehingga tidak bisa hidup sendiri. Manusia dapat memenuhi kebutuhan dan kepentingannya hanya pada saat Ia hidup bermasyarakat. Dengan demikian antara individu dan masyarakat merupakan satu kesatuan yang tidak bisa dipisahkan. Dalam kesatuan hidup bermasyarakat tersebut, terdapat suatu keadaan alamiah yang melekat dalam kehidupan manusia yaitu hidup dalam keselarasan ataupun hidup dalam konflik.

Menurut Satjipto Rahardjo, diantara keselarasan dan konflik tersebut, masyarakat perlu mencapai ketertiban. Ketertiban masyarakat dapat dicapai apabila masyarakat mampu mengelola kebiasaan dan nilai kesusilaan. Kebiasaan merupakan tingkah laku yang bersumber dari naluri alamiah manusia yang muncul sebagai sebuah kepentingan, sedangkan nilai kesusilaan bersumber dari sesuatu di luar diri manusia seperti nilai-nilai agama. Kebiasaan ini seringkali tidak sesuai dengan nilai kesusilaan. ${ }^{1}$

\footnotetext{
${ }^{1}$ Satjipto Rahardjo, Ilmu Hukum, (Bandung : PT Citra Adhitya Bakti, 2012) h. 15
} 
Faktor penyebab diperlukannya pengelolaan kebiasaan manusia dan nilai kesusilaan adalah karena dalam diri manusia terdapat sifat-sifat negative yang perlu dikelola seperti sifat egois, serakah, kejam yang apabila tidak dikelola dapat merugikan individu lainnya. Sedangkan dalam nilai-nilai kesusilaan terdapat berbagai keterbatasan seperti berbedanya masa ditetapkannya nilai kesusilaan, penyampaian bahasanya yang bersifat global, kata yang samar, kata majemuk , kata yang mengandung makna multi tafsir dan sebagainya.

Di Indonesia, pengelolaan kebiasaan manusia dan nilai kesusilaan pada masyarakat tradisional dapat dilakukan dengan perumusan ketentuan adat oleh para tokoh adat. Dalam hal ini kita dapat melihat berbagai rumusan adat dalam kehidupan masyarakat Indonesia seperti adat siraman bagi perempuan yang hendak menikah di daerah Jawa, grebeg di daerah Yogyakarta, uang pelangkah dalam perkawinan dsb.

Sedangkan pengelolaan kebiasaan manusia dan nilai kesusilaan pada masyarakat Indonesia modern menggunakan pendekatan ilmu hukum yang berasal dari Barat. Pengelolaan ini dilakukan oleh para ahli hukum yang mendapatkan wilayah yurisdiksi dalam ranah eksekutif, legislative maupun yudikatif. Berbagai produk hukum di Indonesia sudah dapat kita rasakan diantaranya adalah tentang hukum keluarga yang diatur melalui UU No 1 tahun 1974 dan Kompilasi Hukum Islam. Dalam perlindungan hukum tersebut diharapkan kehidupan keluarga dapat berlangsung secara tertib baik pada saat hidup rukun maupun pada saat mengalami konflik. Pranata keluarga berfungsi sebagai lembaga yang dapat merefleksikan ketenangan dengan adanya kasih sayang serta regenerasi yang bertanggungjawab. Lembaga Mediasi sebagai pranata sosial untuk menyelesaikan konflik secara damai berbasis masa depan para pihak yang berkonflik, serta pengadilan agama sebagai 
pranata sosial untuk menyelesaikan konflik dengan pendekatan pembuktian dan mencari pihak yang benar.

Namun sungguh pun sudah terdapat upaya dalam meramu kebiasaan dan kesusilaan melalui hukum sebagai instrument dalam mewujudkan ketertiban masyarakat masih terdapat sejumlah masalah yang menjadi problematika hukum keluarga di Indonesia sebagai. Masalah tersebut diantaranya adalah tidak tunduknya sebagian masyarakat untuk melakukan pencatatan perkawinan di Kantor Urusan Agama. Adapun faktor yang menyebabkan penolakan pada pencatatan perkawinan diantaranya adalah karena faktor ekonomi atau enggannya menikah di KUA. Disamping faktor tersebut dapat ditemukan juga alasan bahwa pencatatan nikah bukan merupakan bagian dari rukun dan syarat dalam perkawinan menurut Islam sehingga tidaklah penting mencatatakan perkawinannya di lembaga yang ditunjuk pemerintah apabila rukun dan syarat perkawinan yang ada dalam fikih sudah terpenuhi.

Namun sungguhpun terdapat sejumlah persoalan yang menyertai hukum keluarga tersebut namun pemerintah tetap optimis untuk tetap mepertahankan UU No. 1 tahun 1974 dan Kompilasi Hukum Islam itu sebagai dasar legalitas perkawinan atau keluarga.

Fenomena unik tersebut tentu menarik untuk dikaji, dan perlu mengetahui konsep dasar yang ada dalam hukum keluarga di Indonesia dalam kedudukannya sebagai norma sosial. Adapun beberapa hal yang hendak dikaji adalah aspek nilainilai dasar hukum keluarga dan fungsi penerapan atau penegakan hukum keluarga di Indonesia. Berdasarkan pemikiran tersebut maka diususunlah makalah yang berjudul Konsep Dasar Hukum Sebagai Norma Sosial (Studi Analisis Pada UU No. 1 Tahun 1974 dan Kompilasi Hukum Islam) 


\section{Rumusan Masalah}

Penulisan makalah ini memiliki rumusan masalah sebagai berikut:

1. Apa nilai-nilai dasar hukum keluarga sebagai norma sosilal ?

2. Apa yang dimaksud dengan penerapan atau penegakan hukum keluarga?

\section{PEMBAHASAN}

UU No1 tahun 1974 merupakan produk hukum yang diproses melalui jalur legislative dan ditetapkan oleh presiden RI. Sebagai produk legislasi tentu didalamnya mengandung nilai-nilai dan upaya penegakannya. Dalam kesempatanan ini akan konsep dasar hukum keluarga pada aspek nilai dan penegakan hukum dalam UU No 1 tahun 1974 tersebut.

\section{Nilai-Nilai Dasar dalam Hukum Keluarga}

Nilai merupakan istilah yang memiliki makna luas sekali. Dalam kamus bahasa Indonesia, arti nilai secara etimologi adalah harga. Dalam sudut pandang filsafat, nilai merupakan sesuatu yang berguna, sesuatu yang baik, benar, objek yang diinginkan. ${ }^{2}$ Merujuk pada makna filsafat maka nilai-nilai dasar hukum dapat dimengerti sebagai objek yang diinginkan oleh hukum atau suatu tujuan yang ingin dicapai oleh hukum.

Tujuan perumusan hukum telah dibahas oleh banyak Cendekiawan hukum. Di antara pendapat tersebut adalah pendapat Wirjono Projodikoro yang menyatakan bahwa tujuan yang ingin dicapai oleh hukum adalah mewujudkan keselamatan, kebahagiaan dan tata tertib hukum. ${ }^{3}$

\footnotetext{
${ }^{2}$ Louis O.Kattsoff, Pengantar Filsafat, alih bahasa Soejono Soemargono (Jogyakarata : Tiara Wacana, 2004) h. 324

${ }^{3}$ Soeroso, Pengantar Ilmu Hukum, (Jakarta : Sinar Grafika) h. 56
} 
Pendapat lain dapat kita temukan dalam pemikiran R. Subekti yang menyatakan bahwa dasar-dasar tujuan pemerintah dalam merumuskan hukum adalah mewujudkan kemakmuran rakyatnya dengan cara menegakkan keadilan dan ketertiban. Lebih lanjut R. Subekti juga menjelaskan nilai keadilan merupakan anugerah Tuhan Yang Maha Esa yang diberikan kepada manusia. Dalam hal ini setiap manusia diasumsikan dapat menjelaskan apa yang dikehendaki dari nilai keadilan tersebut. ${ }^{4}$

Nilai-nilai dasar hukum atau tujuan hukum juga dijelaskan oleh Radhbruch sebagaimana dikutip oleh Satjipto Rahardjo adalah, keadilan, kemanfaatan dan kepastian hukum. Ketiga nilai tersebut bersifat bertentangan satu sama lain, sehingga dapat saja suatu hukum yang disusun atas satu persepektif tujuan tidak dapat memenuhi perspektif tujuan-tujuan penetapan hukum yang lain. ${ }^{5}$ Oleh karena itu ketepatan dalam memilih tujuan dalam perumusan suatu hukum sangatlah berpengaruh pada efektivitas berlakunya suatu hukum. Semakin tepat dalam memilih nilai-nilai dasar hukum maka masyarakat akan semakin menjunjung tinggi suatu hukum.

Namun pendapat yang menyatakan bahwa nilai-nilai dasar hukum keadilan, kemanfaatan dan kepastian hukum ini saling berlawanan tidak ditemukan dalam tujuan penyusunan Hukum Keluarga di Indonesia. Penyusunan hukum keluarga di Indonesia memiliki dua nilai dasar hukum.

Pertama, Tujuan dari penyusunan hukum keluarga di Indonesia adalah untuk memenuhi keadilan. Rasa keadilan ini misalnya ada dalam pasal mengenai izin poligami, sebagai perimbangan adanya hak suami untuk berpoligami menurut ajaran Islam. Dalam hal ini, penggunaan hak poligami seorang suami atas istrinya

\footnotetext{
${ }^{4}$ Ibid h. 57

${ }^{5}$ Satjipto Rahardjo, Ilmu Hukum, h. 19
} 
harus diketahui dan diizinkan istri karena suami telah terikat kontrak dalam sebuah keluarga. syarat izin poligami berfungsi untuk memastikan apakah poligami yang dilakukan seorang suami akan berdampak negative atau positif terhadap istri dan anak sebagai anggota keluarga. Dalam hal ini diharapkan poligami dilakukan dengan mempertimbangkan kemaslahatan anggota keluarga yang sudah ada. Hal ini sebagaimana dijelaskan dalam pasal 4, pasal 5 UU No 1 thaun 1974. Namun rasa keadilan ini juga tidak hanya ditujukan bagi istri semata namun keadilan bagi suami juga dimana suami diizinkan poligami jika istri tidak diketahui keberadaannya dan jika sudah tidak bisa melakukan perjanjian lagi sebagaimana dijelaskan dalam pasal 6 UU No. 1 Tahun 1974.

Kedua, tujuan kemanfaatan dalam hukum keluarga misalnya ada pada pasal pencatatan untuk menjaga ketertiban perkawinan. Pasal pencatatan perkawinan ini memilki kemanfaatan yang sangat signifikan dalam pembuktian baik untuk kepentingan administrative menyangkut identitas, dalam mengurus akta kelahiran, hak waris dan pembuatan pasport. Disamping itu dapat juga digunakan sebagai alat bukti dalam pengadilan jika diperlukan. Pencatatan perkawinan ini juga ditunjang oleh Peraturan Menteri Agama No 19 tahun 2018.

Disamping itu kemanfaatan yang ada dalam hukum keluarga Islam di Indonesia juga untuk memperbaharui UU No 22 tahun 1946 tentang Pencatatan Nikah, Talak dan Rujuk serta UU No. 32 Tahun 1954 Tentang Pencatatan Nikah dan Rujuk di Seluruh Daerah Luar Jawa dan Madura.

Konten kedua hukum di atas sangat lah tidak seimbang jumlah dan kualitasnya jika dibandingkan dengan UU No. 1 Tahun 1974 Tentang Perkawinan yang disusun lebih sempurna. Terlebih di tahun 1991, UU no 1 Tahun 1974 ini telah diperkuat dengan Instruksi Presiden No 1 tahun 1991 Tentang Kompilasi Hukum 
Islam yang ditujukan bagi umat Islam yang memerlukannya. Dengan demikian nilainilai dasar hukum keluarga yang bertujuan memberikan manfaat pada warga Negara Indonesia dapat terungkap dengan jelas.

Secara implementatif hukum keluarga di Indonesia sudah berfungsi bagi sebagian masyarakat. Namun sebagian lagi belum menundukkan diri pada undangundang tersebut sebagaimana sudah kami ungkapkan dalam latar belakang sebelumnya mengenai adanya keengganan sebagian masyarakat untuk mencatatkan perkawinannya di KUA dikarenakan pencatatan perkawinan tidak berkaitan dengan keabsahan perkawinan. Masyarakat dari kalangan ini belum menyadari bahwa dalam perkawinan yang perlu diatur tidak hanya pada aspek keabsahan perkawinan saja. Pengaturan keabsahan perkawinan itu merupakan satu bagian saja dari rangkaian perjalanan perkawinan yang sangat panjang. Sehingga untuk menjamin ketertiban perkawinan pencatatan perkawinan merupakan langkah selanjutnya untuk memperkokoh aqad perkawinan.

Timbulnya problematika hukum keluarga sebagaimana dijelaskan di atas merupakan hal yang niscaya jika ditinjau dari segi metode perumusan hukum keluarga. Satjipto Rahardjo meperkenalkan metode perumusan hukum dalam tiga metode yang ketiga-tiganya dinyatakan sebagai metode yang sah untuk digunakan, yaitu metode ideal, metode analisis normative dan metode sosiologis. 6

Dalam konsideran UU No 1 tahun 1974 dijelaskan sebagai berikut :

“ Bahwa sesuai dengan falsafah Pancasila serta cita-cita untuk pembinaan hukum nasional, perlu adanya Undang-undang tentang Perkawinan yang berlaku bagi semua warga negara."

\footnotetext{
${ }^{6}$ Menurut Satjipto, metode idealis atau ideologis adalah metode perumusan hukum akan senantiasa berusaha untuk menguji hukum yang harus mewujudkan nilai-nilai tertentu. Metode normative merupakan metode yang bertujuan untuk mewujudkan hukum sebagai lembaga yang bersifat otonom, tidak terikat untuk mewujudkan nilai-nilai tertentu ataupun untuk mencapai sasaran tertentu. Sedangkan metode sosiologis merupakan metode yang dimaksudkan sebagai alat untuk mengatur masyarakat dan mengkaitkan hukum kepada usaha untuk mencapai tujuan-tujuan serta memenuhi kebutuhan konkrit dari suatu masyarakat. Satjipto Rahardjo, Ilmu Hukum, h. 5-6
} 
Demikian juga dalam konsideran Kompilasi Hukum Islam dijelaskan sebagai berikut :

“ Bahwa Kompilasi Hukum Islam dapat digunakan oleh Instansi Pemerintah dan oleh masyarakat yang memerlukannya sebagai pedoman dalam menyelesaikan masalahmasalah di bidang tersebut"

Menyimak pada kedua konsideran dalam hukum keluarga diatas dapat kita tangkap bahwa metode yang digunakan adalah metode normative yang digagas oleh Satjipto Rahardjo. Dalam hal ini pemerintah belum mengukur kebutuhankebutuhan konkrit yang ada dalam masyarakat ketika merumuskan hukum keluarga. Perumusan hukum keluarga didasarkan pada adanya lembaga yang bersifat otonom dan tidak memiliki misi untuk mewujudkan nilai-nilai tertentu maupun sasaran tertentu misalnya sasaran agar selurah masyarakat tunduk pada hukum keluarga.

Pemilihan metode hukum ini sangatlah bisa dimaklumi sebab dalam demokrasi pancasila pemerintah tidak mungkin menerapkan metode ideologis yang bersifat tertutup dan berpihak pada kelompok tertentu saja. Demikian juga pemerintah akan menemukan kesulitan jika menggunakan metode sosiologis yang harus mengukur kebutuhan-kebutuhan masyarakat secara konkrit. Pilihan metode analisis normative merupakan pilihan rasional diantara tiga metode yang ada sebagai fasilitas terbuka bagi masyarakat untuk merasakan pengayoman dari pemerintah.

Fasilitas terbuka tersebut adanya ruang yang memberikan kesempatan pada masyarakat yang belum tunduk pada hukum keluarga untuk melakukan transformasi diri apabila terjadi persoalan menyangkut administrasi Negara seperti mengenai bukti kebasahan perkawinan, akte kelahiran dan bukti harta bersama atau apabila masyarakat telah memiliki pemahaman yang tepat tentang UU No 1 
tahun 1974 dan Kompilasi Hukum Islam. Hal ini sebagai mana di atur dalam kompilasi hukum Islam menyangkut istbat nikah yang diatur dalam pasal 7 ayat 2, ayat 3 dan ayat 4 .

\section{Penerapan atau penegakan Hukum Keluarga di Indonesia.}

Hukum keluarga berasal dari dua kata hukum dan keluarga. Hukum berasal dari kata dari bahasa Arab yang berarti yang dapat melakukan paksaan , memutuskan atau mencegah. ${ }^{7}$ Kata yang senada dengan hukum dalam bahasa asing lainnya yaitu recht yang berarti bimbingan atau tuntutan dalam bahasa belanda. Dalam bahasa Latin istilah yang senada dengan hukum adalah Ius atau iubere yang berarti mengatur atau memerintah. ${ }^{8}$ Pengertian secara termonologis diantaranya disampaikan oleh P. Borst yang dikutip oleh Soeroso bahwa hukum adalah petunjuk yang wajib ditaati. Sedangkan pengertian keluarga dalam kamus besar bahasa Indonesia adalah suatu unit yang terdiri dari Ibu, bapak dan anak-anaknya.

Secara terminologi hukum keluarga adalah keseluruhan ketentuan yang menyangkut hubungan hukum mengenai kekeluargaan sedarah dan kekeluargaan karena perkawinan yang meliputi proses perkawinan, kekuasaan orang tua, perwalian, pengampuan dan keadaan tak hadir. ${ }^{9}$

Hukum keluarga yang sudah disusun sedemikan rupa dengan maksud untuk mewujudkan keadilan dan kemanfaatan bagi masyarakat, selanjutnya perlu diterapkan dalam kehidupan. Proses penerapan tersebut sering disebut dengan istilah penegakan hukum (rechtstoepassing).

Pranata yang sudah disiapkan oleh pemerintah untuk melaksanakan penegakan hukum terdiri dari pranata hukum dan pranata sosial. Pranata hukum

\footnotetext{
${ }^{7}$ Satria Effensi, Ushul Fikih, (Jakarta : Prenada Media grup, 2013), h. 36

${ }^{8}$ Soeroso, Pengantar Ilmu Hukum, h. 24-25

${ }^{9}$ Sudarsono, Hukum Kekeluargaan Nasional ( Jakarta : Rineka Cipta, 1991) h. 1
} 
yang ada adalah pengadilan agama beserta hukum formil dan hukum materilnya, lembaga mediasi. Didalam pranata hukum ini penegakan hukum dilaksanakan oleh penegak hukum jaksa, polisi hakim dan advokat.

Sedangkan pranata sosial yang dapat menunjang penegakan hukum keluarga adalah kantor urusan agama (KUA) dan kantor catatan sipil serta badan penyuluhan dan penasehat pada perkawinan (BP4).

Pranata hukum dan pranata sosial tersebut sudah dapat digunakan sebagian masyarakat. Sehingga dengan demikian hukum keluarga sudah menjadi institusi sosial yang dapat menjamin keadilan dan kemanfaatan hukum keluarga sehingga hukum keluarga sudah berfungsi sebagai norma sosial di Indonesia. ${ }^{10}$

\section{PENUTUP}

\section{A. Simpulan}

Kajian tentang konsep dasar hukum sebagai norma sosial di Indonesia melalui Undang-Undang No 1 tahun 1974 pada aspek nilai-nilai dasar hukum keluarga dan penegakan hukum keluarga di Indonesia berkesimpulan bahwa nilainilai dasar hukum keluarga adalah mewujudkan keadilan dan kemanfaatan di tengah masyarakat. Tujuan tersebut dapat dicapai hanya bila pemerintah dan masyarakat dapat bekerjasama dengan baik dalam mewujudkan tujuan tersebut.

Dalam menunjang tegaknya hukum pemerintah juga sudah membangun pranata hukum dan pranata sosial sebagai instrument penegakan hukum di masyarakat seperti pengadilan, lembaga mediasi.

\section{B. Saran}

Untuk mengimbangi metode perumusan hukum yang bersifat normative maka pemerintah diharapkan lebih mendekatkan pranata sosial di tengah masyarakat. Kantor Urusan Agama Bisa saja diadakan di tingkat kelurahan sebagai kepanjangan tangan KUA di tingkat kecamatan.

\footnotetext{
${ }^{10}$ Institusi sosial merupakan alat kelengkapan masyarakat untuk menjamin agar kebutuhan-kebutuhan dalam masyarakat dapat dipenuhi dengan seksama. Satjipto Rahardjo, Ilmu Hukum, h. 118
} 
Konsep Dasar Hukum Sebagai Norma Sosial: Studi Pada UU No 1 Tahun 1974 Dan Kompilasi Hukum Islam - Suprihatin

\section{DAFTAR PUSTAKA}

Effendi, Satria. 2013. Ushul Fikih, Jakarta, Prenada Media Group.

Pusat Bahasa, t.th., Kamus Besar Bahasa Indonesia, Jakarta, Balai Pustaka

Kattsof, Louis 0. 2004. Pengantar Filsafat, Yogyakarta, Tiara Wacana

Rahardjo, Satjipto. 2012. Ilmu Hukum, Bandung, Citra Adhita Bakti.

Soeroso, 2011, Pengantar Ilmu Hukum, Jakarta, Sinar Grafika

Sudarsono, 1999, Hukum Kekeluargaan Nasional, Jakarta, Penerbit Rineka Cipta. 